\title{
Rancang Bangun Sistem Informasi Manajemen Arsip Digital
}

\author{
Anisah $^{[1]}$, Delpiah Wahyunigsih ${ }^{[2]}$, Ellya Helmud ${ }^{[3]}$, Tedy Suwanda ${ }^{[4]}$, Parlia Romadiana ${ }^{[5]}$, Devi Irawan ${ }^{[6]}$ \\ Fakultas Teknologi Informasi ${ }^{[1], ~[2], ~[3], ~[4], ~[5],[6] ~}$ \\ Institut Sains dan Bisnis Atma Luhur \\ Pangkalpinang, Indonesia \\ $\underline{\text { anisah@atmaluhur.ac.id }}{ }^{[1]}$, delphibabel@ atmaluhur.ac.id ${ }^{[2]}$,Ellyahelmud@atmaluhur.ac.id ${ }^{[3]}, 1722510025$ \\ @ mahasiswa.atmaluhur.ac.id ${ }^{[4]}$, parlia@ $\underline{\text { atmaluhur.ac.id }}^{[5]}$, deviirawan@ atmaluhur.ac.id $^{[6]}$
}

\begin{abstract}
Digital archive management has now become an option for both government and private agencies. because it can streamline the storage area, facilitate data collection, facilitate tracking and monitoring of archives. Searching archives manually certainly takes a long time, compared to using a digital system that already utilizes a Database Management System (DBMS) to store existing archives. As happened at the BPKP Representative office of the Bangka Belitung Islands Province, archive storage from various fields still uses filing cabinets. The increasing volume of archives from day to day is a serious problem because it takes a long time to search for the desired archive and it is difficult to monitor archives in various fields in the agency. So that a web-based digital archive management becomes a solution to the existing problems. The analysis and design method uses Object Oriented Analysis and Design (OOAD) and the database uses MySQL. The resulting archive management is able to speed up the archive search process and monitor the movement of archives from various fields in the agency.
\end{abstract}

Keywords- Information System, Records Management, Database Management System.

Abstrak - Management arsip digital saat ini sudah menjadi pilihan baik pada instansi pemerintah maupun swasta. dikarenakan dapat mengefisienkan tempat penyimpanan, memudahkan pendataan, memudahkan penelusuran dan monitoring terhadap arsip serta lebih rapinya pengarsipan surat-surat atau dokumen yang ada pada institusi. Penelusuran arsip secara manual tentu membutuhkan waktu yang agak lama, dibandingkan dengan menggunakan sistem digital yang sudah memanfaatkan Database Management System (DBMS). Dalam hal ini, kantor Perwakilan BPKP Provinsi Kepulauan Bangka Belitung yang menjadi salah satu sasaran untuk mengembangkan sistem manajemen arsip digital yang mana sistem yang berjalan saat ini untuk penelusuran dan penyimpanan arsip dari berbagai bidang masih menggunakan lemari arsip/menggunakan sistem yang manual. Meningkatnya volume arsip dari hari ke hari menjadi permasalahan yang serius karena dibutuhkan waktu yang lama untuk melakukan pencarian arsip yang diinginkan dan sulitnya memonitor arsip di berbagai bidang pada instansi. Sehingga sebuah management arsip digital berbasis web menjadi solusi atas permasalah yang ada. Metode analisis dan perancangan menggunakan Object Oriented Analisys and Design( OOAD) dan database menggunakan MySQL. Management arsip yang dihasilkan mampu mempercepat proses pencarian arsip dan memonitor pergerakan arsip dari berbagai bidang pada instansi.

Kata Kunci- Sistem Informasi, Manajemen Arsip, Database Management System

\section{PENDAHULUAN}

Perwakilan BPKP Provinsi Kepulauan Bangka Belitung saat ini, terkait dengan pencarian arsip dan penyimpaan arsip masih menggunakan sistem secara manual. Dengan adanya pencarian arsip secara manual tersebut, saat ingin mencari informasi terkait arsip membutuhkan waktu yang lama apalagi dengan kondisi jumlah volume arsip yang semakin besar dari tahun ke tahun.

Management arsip digital saat ini sudah menjadi pilihan yang sangat dibutuhkan baik pada instansi pemerintah maupun swasta. Dikarenakan dapat mengefisienkan tempat penyimpanan, memudahkan pendataan, memudahkan penelusuran dan monitoring terhadap arsip serta lebih rapinya pengarsipan surat-surat atau dokumen yang ada pada institusi. Arsip merupakan salah satu sumber informasi dalam suatu organisasi baik organisasi pemerintah ataupun organisasi swasta yang tentunya memiliki peranan penting dalam kelangsungan hidup perusahaan karena arsip memiliki berbagai informasi yang dapat dijadikan sebagai alat bukti pertanggungjawaban ataupun sebagai alat pendukung dalam mengambil suatu keputusan. [1].

Beberapa studi pustaka terkait dengan sistem manajemen arsip, menjadi acuan dalam melakukan analisi sistem informasi manajemen arsip digital yang ada di Perwakilan BPKP Provinsi Kepulauan Bangka Belitung.

Penelitian terkait arsip ini pernah dilakukan oleh Nor 
Haniah, dkk dengan judul: "Rancang Bangun Sistem Pengarsipan Surat Pada Kantor DPRD Kota Banjarmasin Berbasis Web Menggunakan Framework Codeigniter", dalam penelitian ini, metode yang digunakan adalah waterfall, diagram konteks untuk perancangan sistem, DFD level 1 dan relasi antar table. Teknik pengumpulan data yang digunakan adalah observasi, wawancara langsung dan studi pustaka. Alat bantu menggunakan sublime text, xampp. DBMS yang digunakan adalah MySQL dengan menggunakan Bahasa pemrograman php framework codeigniter, pengujian pada sistem ini menggunakan blackbox testing dan hasilnya sistem dapat melakukan pencarian secara cepat serta semua fitur sudah berfungsi sesuai yang diharapkan[2]. Penelitian selanjutnya dilakukan oleh R. P. Bendriyanti and L. N. Zulita dengan judul "Implementasi E-Arsip Pada Kanwil Kementerian Agama Provinsi Bengkulu”. Dalam penelitian ini dilakukan Pembuatan Implementasi E-Arsip pada Kanwil kementrian Agama agar proses pencarian data dan informasi arsip menjadi lebih mudah dan adanya kesempurnaan dalam melakukan penyelenggaraan kearsipan yang selama ini masih menggunakan sistem yang manual. Metode pengumpulan data dengan observasi dan studi pustaka serta pembuatan perangkat lunak melalui analisis dan desain secara terstruktur[3]. Penelitian selanjutnya terkait dengan manajemen arsip pernah dilakukan oleh W. Pamulasari dkk dengan judul "Rancang Bangun Sistem Informasi Manajemen Surat Berbasis Web Pada Kantor Bpjs Ketenagakerjaan Cabang Sukabumi”. Penelitian ini bertujuan untuk memudahkan sekretaris, kepala cabang, kepala bidang, dan staf BPJS Ketenagakerjaan untuk melihat informasi terkait disposisi surat sehingga persuratan yang ada dapat dikelola dengan baik. Metode yang digunakan dala membangun sistem ini adalah Waterfall dan Tools yang digunakan adalah UML (Unified Modeling Language). Sistem yang dihasilkan dapat membantu proses pengelolaan surat/arsip, proses penyimpanan serta pencarian arsip surat [4]. Penelitian dilakukan oleh Latif, Raden Abdul Effiyaldi dengan judul "Analisis Dan Perancangan Sistem Informasi Manajemen Arsip Berbasis Web Pada Sekretariat DPRD Kota Jambi", penelitian ini melakukan proses analisa dan merancang suatu prototype Sistem Informasi Manajemen Arsip surat masuk dan surat keluar yang berbasis web, metode pemodelan sistem yang digunakan adalah dengan menggunakan UML (Unified Modeling Language). Adapun sistem yang dirancang meliputi fitur pengelolaan data admin, data pengguna, data arsip, peminjaman arsip, laporan, mengirim dan menerima arsip dan keamanan arsip, sehingga sistem yang terkomputerisasi ini merupakan solusi permasalahan kearsipan yang ada pada Sekretariat DPRD [5]. Penelitian A'id, A M dan Megayanti, A Sistem Manajemen Arsip Terpadu Berbasis Mobile Android Dalam Menunjang Efesiensi Kerja Pt. Krakatau Steel. Penelitian ini mneggunakan metode metode Research and Development, sistem manajemen arsip secara terpadun yang dikembangkan dapat mempercepat dan meningkatkan efektifitas kinerja yang di lakukan oleh seluruh karyawan Krakatau Steel [6]. Penelitian yang dilakukan oleh Irawan, Muhammad Dedi dan Simargolang, Selli Aprilla dengan judul" Implementasi E-Arsip Pada Program Studi Teknik Informatika", t. Metode pengumpulan data yang digunakan adalah melalui observasi dan studi pustaka. Untuk iimplementasi mengguakan bahasa pemgoraman PHP. Editor yang digunakan adalah notepad ++ dan menggunakan database XAMPP. Sistem e arsip berbasis web yang dihasilkan dapat membantu proses penyelenggara kearsipan yang sesuai dengan prinsip sehingga proses proses pencarian data dan informasi arsip menjadi lebih mudah, dan lebih akurat. [7]. Penelitian Taufik, Ghofar yang berjudul "Extreme Programming Guna Rancang Bangun Sistem Informasi Pengarsipan Dokumen". Penelitian ini menggunakan model extreme programming (XP). Model yang digunakan ini akan mengakomodir setiap kebutuhan dalam melakukan pengarsipan sehingga dengan adanya sistem ini dokumen yang ada dapat disimpan dengan baik. [8]. Penelitian yang dilakukan oleh Suryadi, dengan judul "Rancang Bangun Sistem Pengelolaan Arsip Surat Berbasis Web Menggunakan Metode Waterfall (Studi Kasus : Kantor Desa Karangrau Banyumas)”. Metode yang digunakan adalah waterfall, diimplementasikan dengan menggunakan PHP Hypertext Prepocessor (PHP) dan database yang digunakan adalah MySQL. Penelitian ini menghasilkan sebuah sistem informasi yang dapat mengelola surat masuk dan surat keluar sesuai alur yang ditetapkan, dan dapat menyelesaikan masalah yang ada saat ini.[9]. Penelitian yang dilakukan oleh Ghozi, Muhamad dan Irfan, Dedy dengan judul " Pengembangan Sistem Informasi Manajemen Arsip dan Disposisi Surat Berbasis Web Di Bpn Kota Padang". Sistem yang dibuat menggunakan metode analisis dan perancangan sistem, menggunakan framwrork codeigniter, bahasa pemrograman php, dan database yang digunakan adalah MySQL. Sistem yang dihasilkan dapat membuat Tata Usaha dalam mengelola arsip, sehingga penyimpanan data arsip menjadi lebih rapi.

[10]

\section{Metodologi Penelitian}

Metode yang digunakan dalam penelitian ini adalah menggunakan waterfall. Model waterfall merupakan suatu metode pengembangan perangkat lunak yang menggunakan pendekatan terhadap perangkat lunak secara sistematik dan sekuensial. Tahapan meliputi analisis, design, kode, pengujian dan pemeliharaan. Setiap tahap harus diselesaikan secara sistematik, tahap selanjutnya baru bisa dijalankan jika tahapan sebelumnya telah selesai dilakukan [11]. Berikut ini tahapan dalam pengembangan sistem yang ada pada model waterfall yang dapat dilihat pada Gambar 1. 


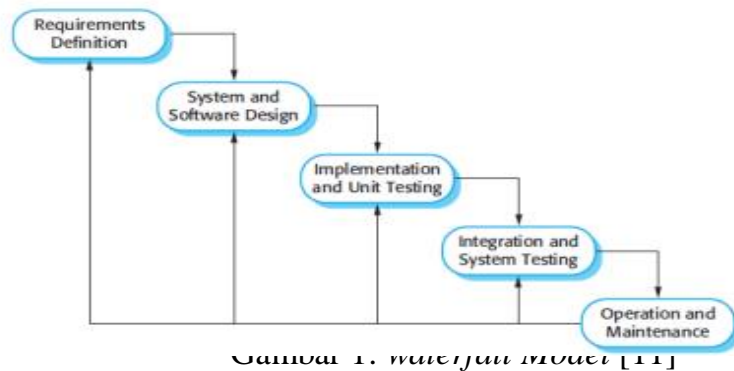

Berdasarkan model pengembangan sistem tersebut, 4 tahapan akan digunakan dalam penelitian ini.

1) Requirements Definition

Untuk mendefiniskan kebutuhan sistem pengarsipan yang ada di perwakilan BPKP Provinsi Kepulauan Bangka Belitung, dilakukan proses pengumpulan data melaui proses wawancara langsung dengan narasumber yang mengurusi bagian arsip sehingga diperoleh gambaran proses bisnis sistem berjalan yang ada di sana yaitu meliputi bagaimana proses pencatatan data arsip, bagaiman proses pengumpulan dan pengelompokan data arsip, proses pemantauan dan pelaporan data arsip . sehingga dari proses bisnis sistem yang berjalan dilakukan analisis untuk mengidentifikasikan kebutuhan sistem manajemen arsip yang ada.

2) System and Software Design

Pada tahapan ini, dilakukan perancangan basis data dan perancangan layar yang disesuaikan dengan hasil kebutuhan sistem usulan.

\section{3) Implementation and Unit Testing}

pada tahapan ini dilakukan proses coding system pada aplikasi yang dibuat. Untuk implementasi software dibuat menggunakan berbasis web dengan menggunakan bahasa pemrograman PHP dan database MySQL

\section{HASIL DAN PEMBAHASAN}

\section{A. Requirements Definition}

1) Proses Bisnis Sistem Berjalan

Proses bisnis sistem berjalan yang didapatkan berdasarkan hasil wawancara langsung dengan narasumber dijelaskan dengan menggunakan activity diagram :
- Activity Diagram Proses Pencatatan Data Arsip

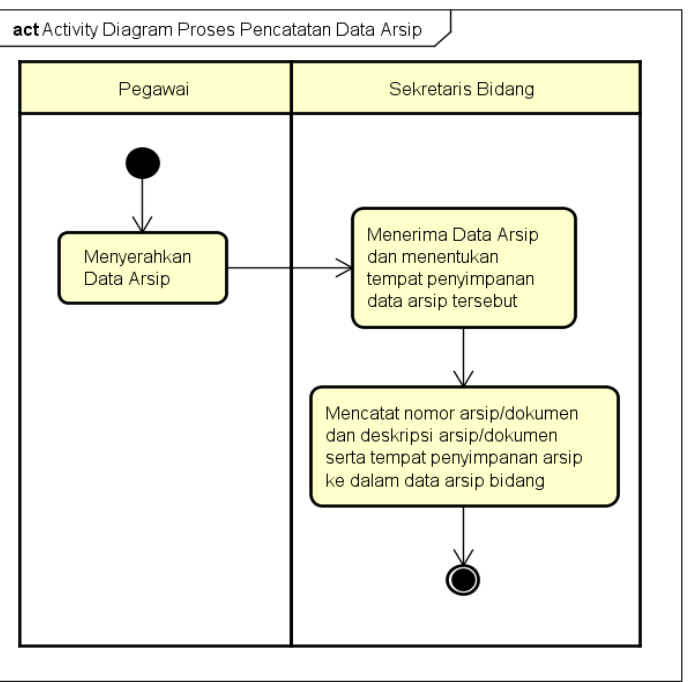

Gambar 1

Activity Diagram Proses Pencatatan Data Arsip

Gambar 1: Activity Diagram Proses Pencatatan data Arsip yang terdapat pada gambar 1 melibatkan bagian pegawai dan bagian sekretaris bidang. Dimanadata arsip akan disimpan di bagian sekretaris bidang.

- Activity Diagram Proses Proses Pengumpulan dan Pengelompokan Data Arsip

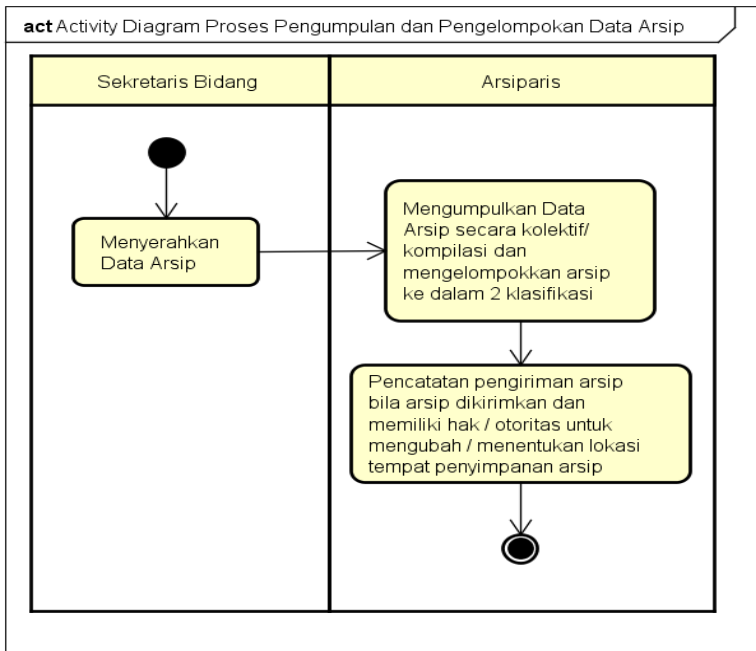

Gambar 2.

Activity Diagram Proses Pengumpulan dan Pengelompokan Data Arsip

Gambar 2: Activity Diagram proses pengumpulan dan pengelompokan data arsip yang terdapat pada gambar 2 melibatkan bagian sekretaris bidang dan bagian arsiparis. 
- Activity Diagram Proses Pemantauan dan Pelaporan Data Arsip.

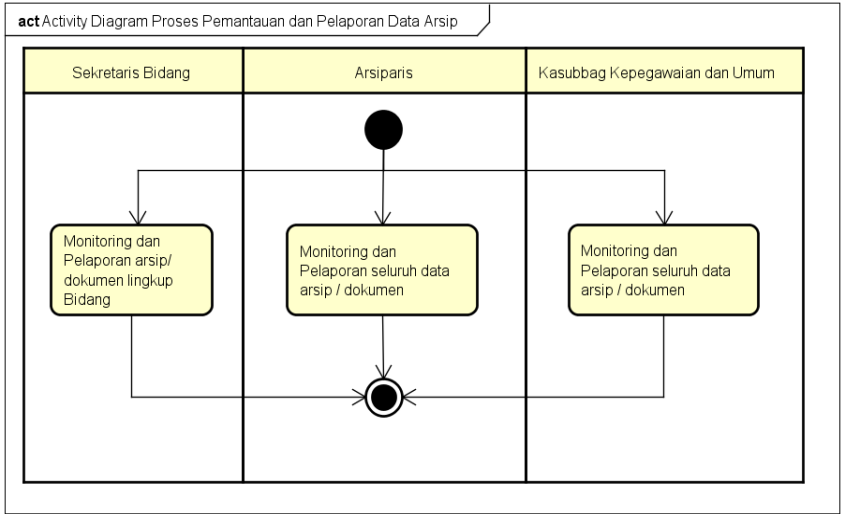

Gambar 3. Activity Diagram Proses Pemantauan dan Pelaporan.

Gambar 3: Activity Diagram Proses Proses Pemantauan dan Pelaporan yang terdapat pada gambar 3 melibatkan sekretaris bidang, bagian arsiparis, kasubag kepegawaian dan umum.

2) Kebutuhan Sistem yang diusulkan

Kebutuhan sistem usulan ini dihasilkan berdasarkan hasil analisis terhadap sistem yang berjalan dan analisis terhadap dokumen sistem berjalan. Adapun kebutuhan sistem yang diusulkan tergambar pada usecase diagram berikut ini:

- Use Case diagram untuk admin

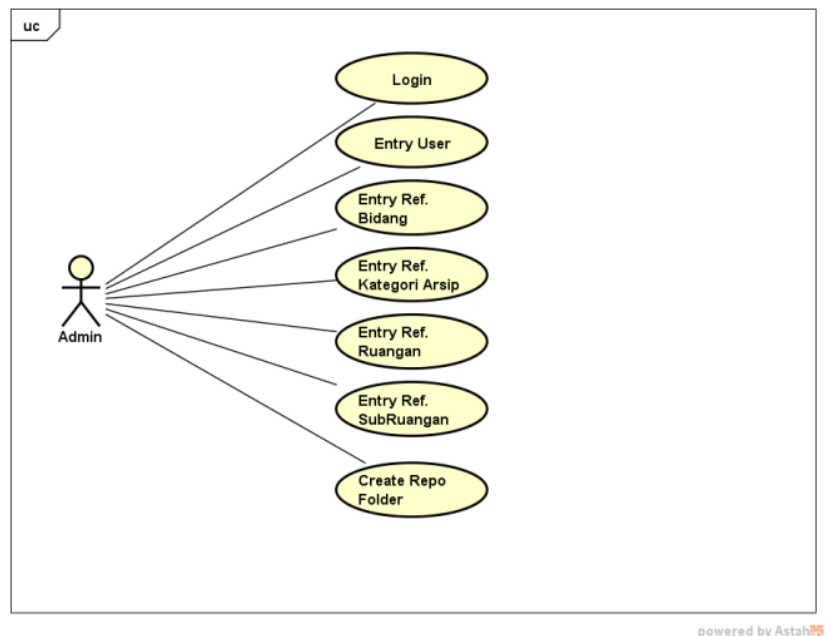

Gambar 4. Use case diagram untuk admin

Gambar 4: Use case diagram yang aktornya adalah admin pada gambar 4 akan melakukan login ke sistem, entry user, entry ref bidang, entry ref. kategori arsip, entry ref. ruangan, entry ref..sub ruangan, create Repo Folder.

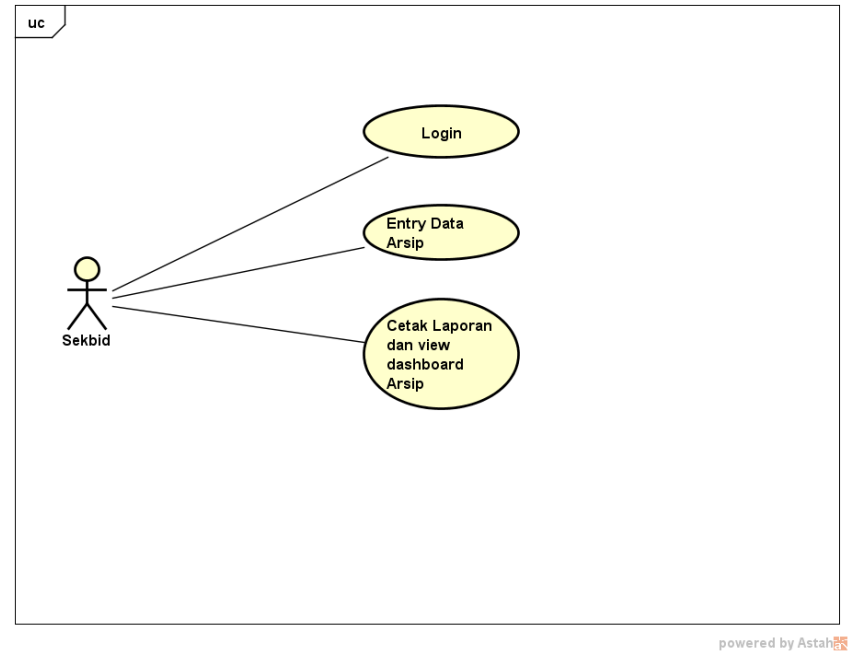

Gambar 5. Use case Diagram Sekretaris Bidang

Gambar 5:Use Case Diagram sekretaris bidang bisa berinteraksi dengan sistem dengan login terlebih dahulu, kemudian bisa melakukan entry arsip dan bisa melakukan pencetakan dan view arsip.

- $\quad$ Use case diagram Arsiparis

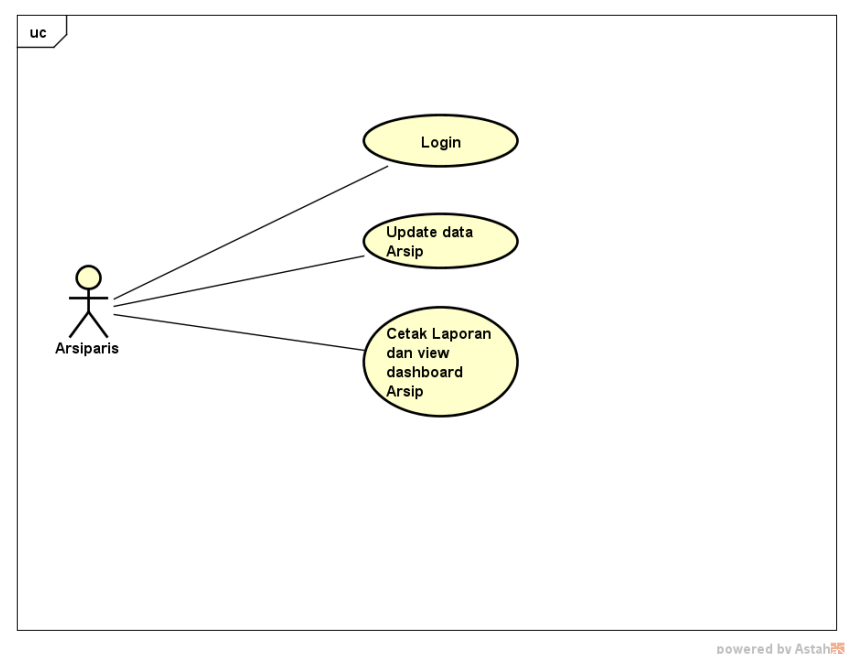

Gambar 6. Use Case Diagram Arsiparis

Gambar 6:Use case diagram bagian arsiparis bisa berinteraksi dengan sistem dengan login terlebih dahulu, kemudian bisa untuk melakukan update data arsiparis, selain itu juga bisa melakukan pencetakan laporan dan view dashboard arsip.

- Use Case Diagram Sekretaris Bidang 
- Use case diagram Kasubag kepegawaian dan umum

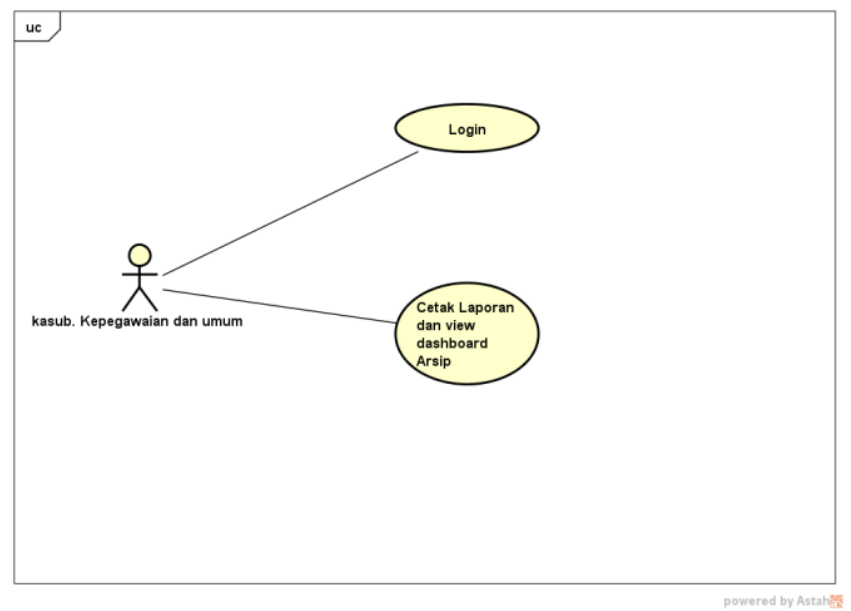

Gambar 7. Use case diagram Kasubag Kepegawaian dan Umum

Gambar 7: Use case diagram kasubag kepegawaian dan umum pada gambar 7 bisa melakukan interaksi dengan sistem dengan melakukan login terlebih dahulu, kemudian bisa melakukan cetak laporan dan view dashboard Arsip.

\section{B. System and Software Design}

1) Perancangan/Desain sistem

Tujuan desain sistem bertujuan untuk memenuhi kebutuhan pemakai sistem serta memberikan gambaran yang jelas dan rancang bangun yang lengkap untuk nantinya digunakan untuk pembuatan program komputer.[12]. Analisis dan perancangan berorientasi objek merupakan suatu cara untuk memikirkan suatu permasalahan dengan memodelkannya menurut konsep dari dunia nyata. Berikut ini adalah hasil rancangan objek yang sesuai dengan kebutuhan sistem usulan yang digambarkan dalam bentuk class diagram seperti gambar di bawah ini:

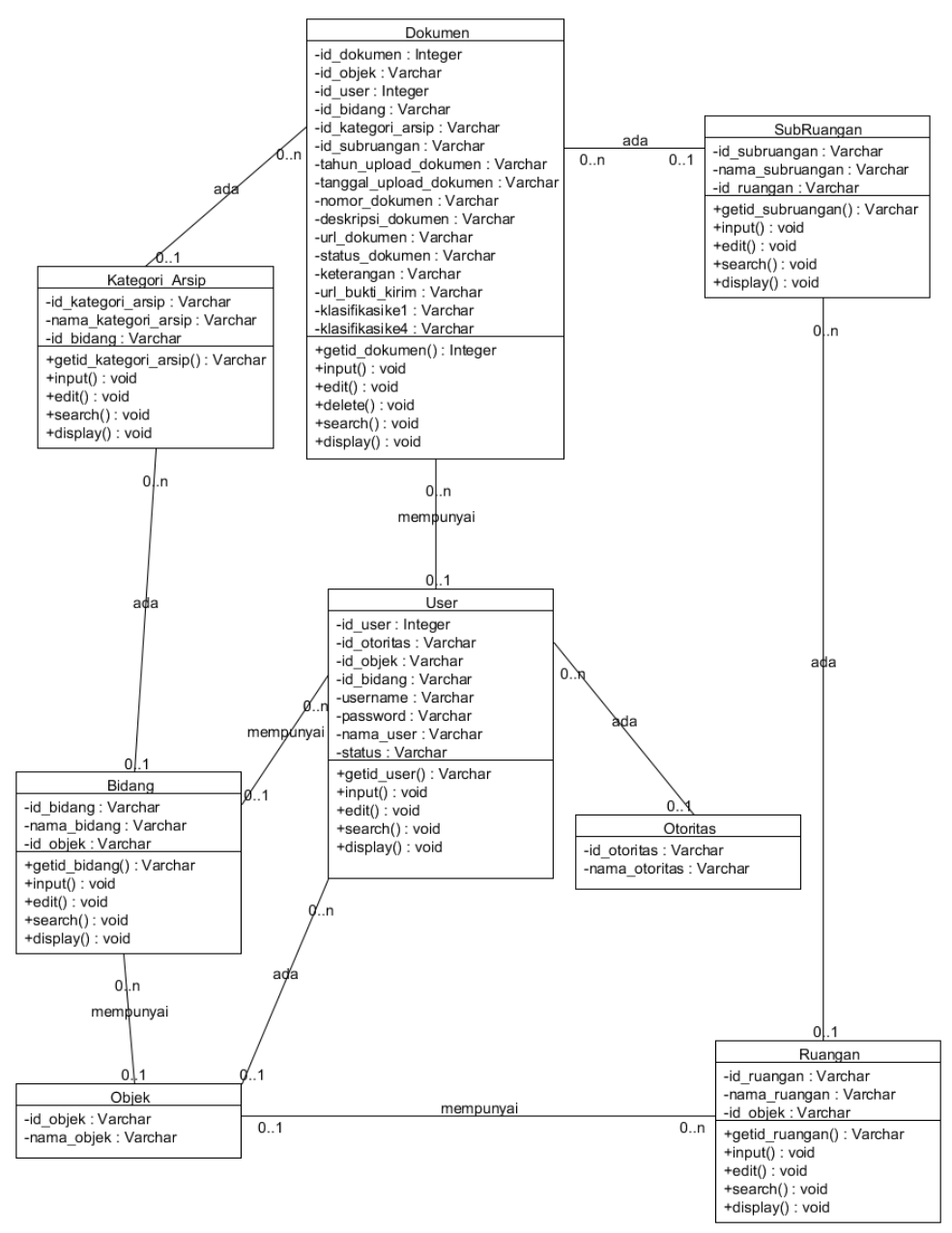

Gambar 8. Class Diagram

Gambar 8: Class diagram pada gambar 8 terdapat beberapa objek/class yang dapat dirancang yang nantinya datanya akan tersimpan di database diantaranya adalah class dokumen, class subruangan, class ruangan, class kategori arsip, class otoritas, class bidang dan class objek. Dimana class ruangan berasosiasi dengan class subruangan, dan class subruangan berasosiasi dengan dokumen, dokumen berasosiasi dengan kategori arsip, dan dokumen berasosiasi dengan user, dan user berasosiasi dengan class otoritas, class kategori arsip berasosiasi dengan class bidang, dan class bidang berasosiasi dengan class objek. 


\section{2) Perancangan Layar/interface input dan output}

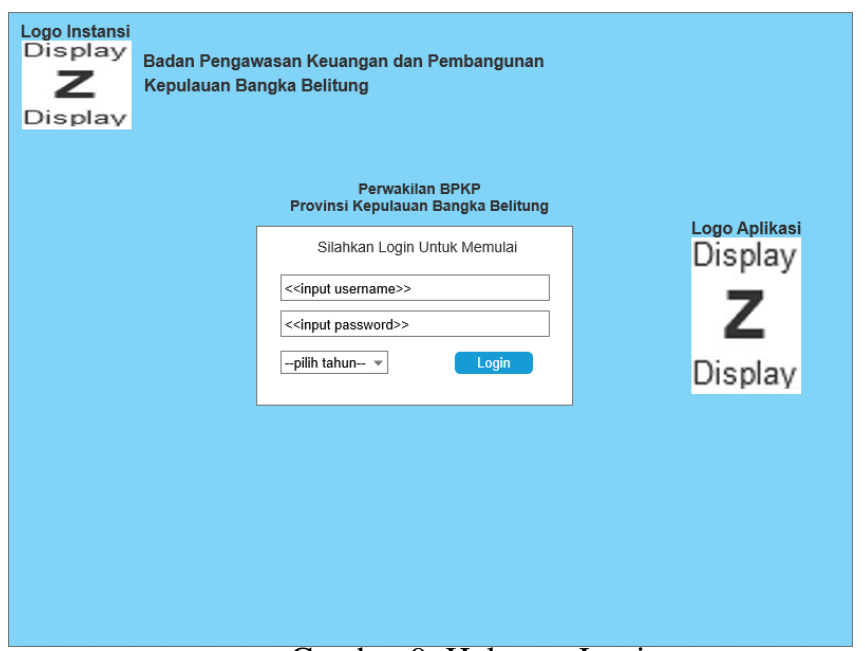

Gambar 9. Halaman Login

Gambar 9: Halaman login yang ada pada gambar 9 merupakan halaman awal aktor sistem sebelum masuk ke menu utama masing-masing actor. Actor yang nantinya akan berinteraksi dengan sistem adalah Admin, sekbid, Arsiparis, kasubag kepegawaian dan umum.

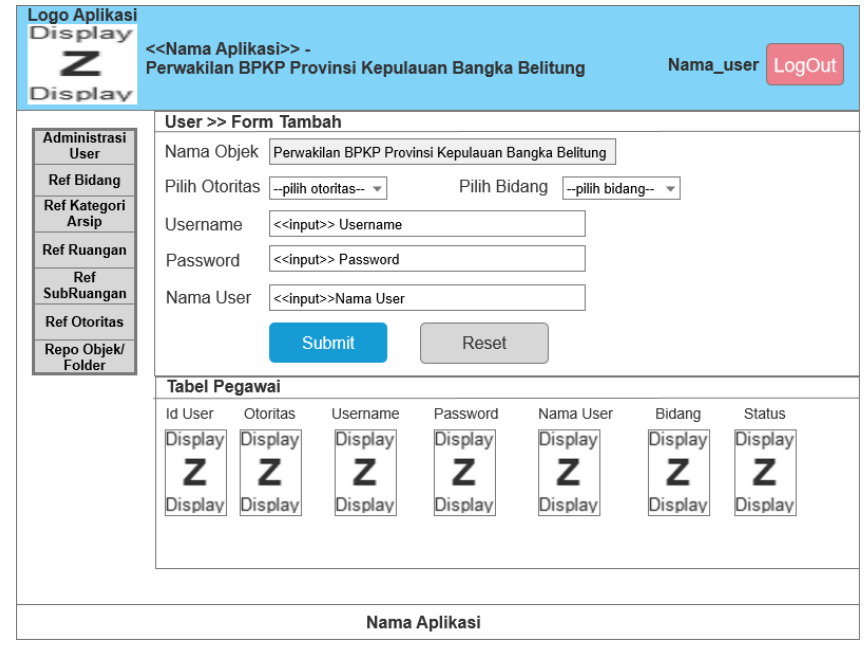

Gambar 10. Halaman Utama Admin untuk Entry Data

User

Gambar 10: merupakan halaman utama dari aktor admin dan salah satu halaman inputan untuk melakukan penginputan data user ke dalam sistem.

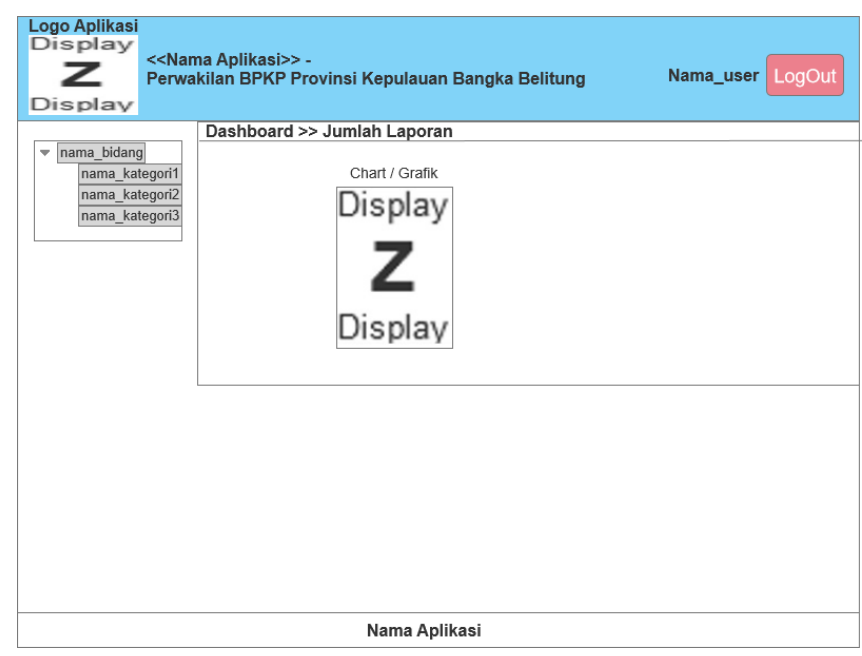

Gambar 11. Halaman Utama Sekretaris Bidang

Gambar 11: Rancangan pada gambar 11 merupakan halaman utama dari sekretaris bidang yang menampilkan data terkait kategori dari arsip.

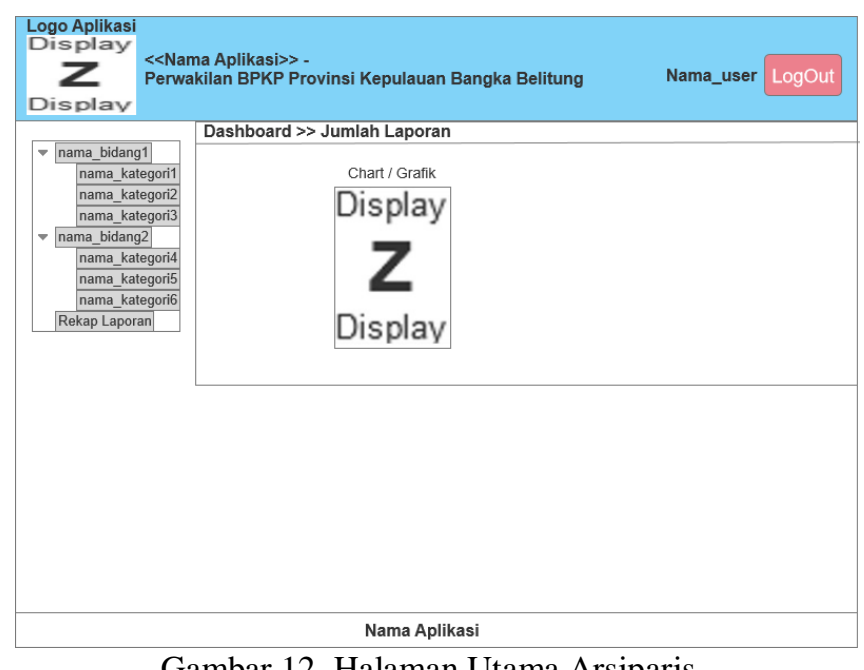

Gambar 12. Halaman Utama Arsiparis

Gambar 12: Rancangan layar pada gambar 12 merupakan halaman utama bagian arsiparis yang terdiri dari menu untuk mengupdate arsip dan menampilkan mencetak laporan arsip.

\section{Implementation and Unit Testing}

Sistem yang sudah dianalisis dan dirancang akan diimplementasikan dengan menggunakan suatu aplikasi berbasis web, dengan menggunakan DBMS MySQL 


\section{KESIMPULAN DAN SARAN}

Kesimpulan dari penelitian ini adalah sebagai berikut:

Sistem yang berjalan saat ini masih menggunakan sistem manual yang mengalami kendala terkait pencarian/penelusuran data yang membutuhkan waktu dalam hitungan hari, dibandingkan dengan menggunakan sistem digital yang memanfaatkan databasae Management System (DBMS) yang bisa menghasilkan informasi dalam hitungan detik. Serta kurang efisiennya tempat penyimpanan karena membutuhkan ruangan yang besar untuk menampung data, sehingga perlu dikembangkan menjadi sebuah sistem informasi arsip yang terkomputerisasi untuk mengatasi permasalahan yang ada

Aplikasi yang dibangun berguna bagi admin, sekretaris bidang, Arsiparis, dan bagian kepegawaian dan umum untuk melakukan proses pendataan arsip, proses penyimpanan arsip, proses penelusuran arsip, dan proses menampilkan infromasi terkait arsip yang mereka butuhkan.

Aplikasi yang dibuat dapat mengefisienkan tempat penyimpanan, memudahkan pendataan, memudahkan penelusuran dan monitoring terhadap arsip yang ada.

Adapaun saran untuk penelitian selanjutnya adalah:

Aplikasi yang telah dibangun dapat dikembangkan kembali menjadi aplikasi yang lebih baik dengan menambahkan fitur-fitur tertentu.

Penelitian selanjutnya bisa membahas terkait kepuasan pengguna terhadap sistem yang sudah dibangun.

\section{REFERENCES}

[1] I. Sontana, A. Rahmatulloh, and A. N. Rachman, "Application Programming Interface Google Picker Sebagai Penyimpanan Data Sistem Informasi Arsip Berbasis Cloud," J. Nas. Teknol. dan Sist. Inf., vol. 5, no. 1, pp. 25-32, 2019.

[2] N. Haniah and A. Ardi, "RANCANG BANGUN SISTEM PENGARSIPAN SURAT PADA KANTOR DPRD KOTA BANJARMASIN BERBASIS WEB MENGGUNAKAN FRAMEWORK CODEIGNITER," Phasti J. Tek. Inform. Politek. Hasnur, vol. 5, no. 02, pp. 36-40, 2019.

[3] R. P. Bendriyanti and L. N. Zulita, "Implementasi EArsip Pada Kanwil Kementerian Agama Provinsi Bengkulu," J. Media Infotama, vol. 8, no. 1, 2012.

[4] W. Pamulasari and N. Suryana, "RANCANG BANGUN SISTEM INFORMASI MANAJEMEN SURAT BERBASIS WEB PADA KANTOR BPJS KETENAGAKERJAAN CABANG SUKABUMI," ENSAINS J., vol. 3, no. 1, pp. 34-41, 2020.

[5] R. A. Latif and E. Effiyaldi, "Analisis Dan Perancangan Sistem Informasi Manajemen Arsip Berbasis Web Pada Sekretariat DPRD Kota Jambi," J. Manaj. Sist. Inf., vol. 5, no. 2, pp. 210-222, 2020.

[6] A. M. A'id and A. Megayanti, "Sistem Manajemen Arsip Terpadu Berbasis Mobile Android Dalam
Menunjang Efesiensi Kerja Pt. Krakatau Steel,’ J. Ilm. Sains dan ..., 2020.

[7] M. D. Irawan and S. A. Simargolang, "Implementasi E-Arsip Pada Program Studi Teknik Informatika," JurTI (Jurnal Teknol. Informasi), vol. 2, no. 1, pp. 6784, 2018.

[8] G. Taufik, "Extreme Programming Guna Rancang Bangun Sistem Informasi Pengarsipan Dokumen," BINA Insa. ICT J., vol. 5, no. 1, pp. 11-20, 2018.

[9] A. Suryadi, "RANCANG BANGUN SISTEM PENGELOLAAN ARSIP SURAT BERBASIS WEB MENGGUNAKAN METODE WATERFALL (STUDI KASUS : KANTOR DESA KARANGRAU BANYUMAS)," J. Khatulistiwa Inform., 2019, doi: 10.31294/jki.v7i1.36.

[10] M. Ghozi and D. Irfan, "PENGEMBANGAN SISTEM INFORMASI MANAJEMEN ARSIP DAN DISPOSISI SURAT BERBASIS WEB DI BPN KOTA PADANG," VoteTEKNIKA J. Vocat. Tek. Elektron. dan Inform., vol. 6, no. 2, pp. 113-121, 2018.

[11] Sommerville, Ian, 2011,Software Engineering (Rekayasa Perangkat Lunak). Jakarta : Erlangga.

[12] M.Firman Arif, S.Kom., M.Kom, 2019, Analisis dan Perancangan Sistem Informasi, penerbit: Qiara Media 